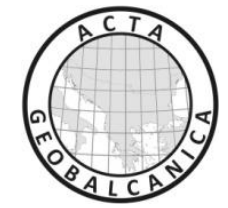

\title{
FLOOD INUNDATION MAPPING BY GIS AND A HYDRAULIC MODEL (HEC RAS): A CASE STUDY OF AKARCAY BOLVADIN SUBBASIN, IN TURKEY
}

\author{
Yilmaz İcaga ${ }^{1}, \operatorname{Emin}^{\operatorname{Tas}^{1}}{ }^{\&}$ Murat Kilit ${ }^{1}$ \\ ${ }^{1}$ Afyon Kocatepe University, Turkey \\ Corresponding author: emintas@aku.edu.tr
}

\begin{abstract}
In this study, it is aimed to constitute flood inundation maps for Akarcay Bolvadin Subbasin. Topographic data of study area is defined for hydraulic model by sectioning along the river on Digital Elevation Model (DEM) which is created by ArcGIS, a Geographical Information System (GIS) software. It is used HEC RAS software as hydraulic model. Data migration between ArcGIS and HEC RAS is provided by using an intermediate module, HEC GeoRAS. After required geometrical and hydraulic structure data are constituted, flood inundation maps are obtained by inputting flow data into the model. Flow data is calculated by Fuller Method for various recurrence intervals. In consequence of hydraulic modelling, flood depth and velocity values are also acquired. The areas at flooding risk are determined by taking account of flood inundation, depth and velocity data. And it is given several suggestions for take due precautions in these areas.
\end{abstract}

Keywords: Flood inundation, GIS, HEC RAS, Hydraulic Modelling, Fuller Method.

\section{INTRODUCTION}

Flood disaster is a natural disaster, which can stated water quantity on streambed upsurges because of storm and/or snow melt and causes towering loss of life and property; but it is impossible to express depending on only meteorological occurrences. In developing countries such as Turkey, hydrological balance is disrupted by factors as rapid growth of settlements and irregular urbanization depending on population increase and industrialization. In conclusion, major flood disasters are experienced. In this respect, consisted by effecting many factors flood disaster is a difficult problem in producing solutions that causes large economical and many life losses. Therefore it is obligatory to take preventive or reducing damage precautions against flood $[1,2,3]$. In the world, 2887 flood events were eventuated between the years of 1980-2008, causing about 200 thousand people died, about 2.8 billion people affected and about 398 billion $\$$ economic damage [4]. Flood events can cause widespread disruption and damage, and loss of life, particularly if flood waters are deep, fast flowing or have a high debris content, and when flooding occurs at night or at low temperatures. For example, during 2007, a year which saw extensive flooding in China and some 20 countries in Africa, and due to the Asian monsoon, more than 177 million people were affected by flooding, causing more than US\$ 20 billion of damages [5]. 
It is easily stated that many human activities devoid of environmental conscience increase substantially effect of flood disaster. In this context, making risk based flood management plans has great importance. It is aimed to give some recommendations for preventing/reducing flood damage in Akarcay Bolvadin Subbasin by assessing flood risk in this paper.

\section{MATERIAL AND METHODS}

In this study, it is determined water levels and submerged areas for various return periods by using GIS based hydraulic model in Akarcay Bolvadin Subbasin. Primarily, study area border is determined by considering several criteria. Physical and human geography features (elevation, slope, aspect, climate, settlement, land cover etc) of basin are studied to analyze basin characteristics for flood risk potential assessment. In the same time, required geometric data for hydraulic model is formed on GIS by an intermediate module (HEC GeoRAS). Afterwards, flood discharges are calculated to input into the model for various probabilities of exceedance. Finally, hydraulic model is performed in the light of information acquired. Flow chart of flood mapping by GIS based hydraulic modelling is given in Figure 1.

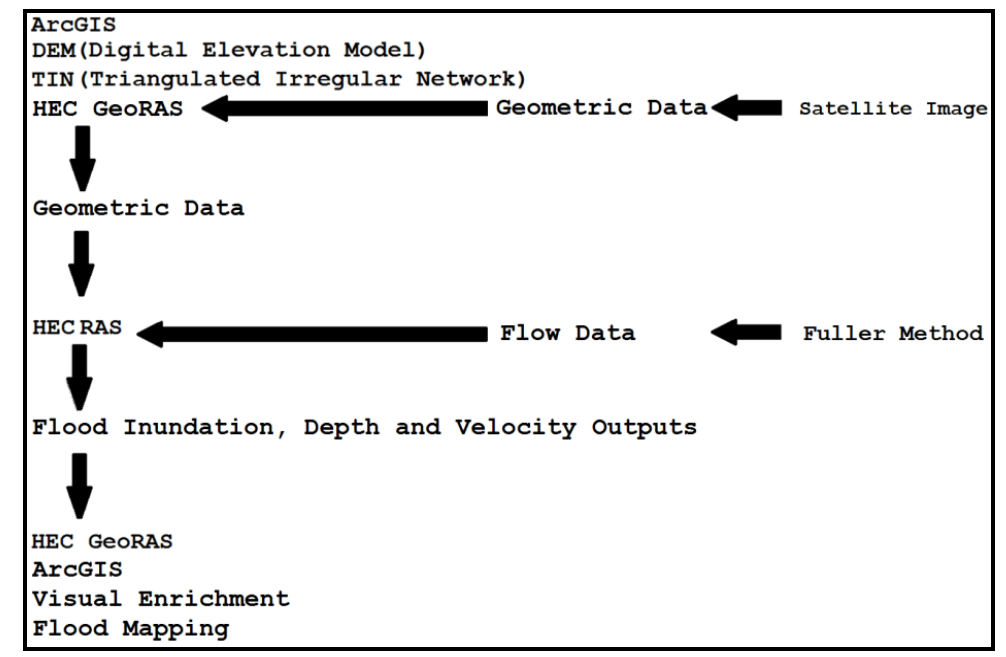

Figure 1. Flow chart of flood mapping by GIS based hydraulic modelling

Study Area: Akarcay Basin $\left(7605 \mathrm{~km}^{2}\right)$ is a closed basin, in joint area of Aegean, Mediterranean and Central Anatolia Regions of Turkey. Akarcay River is most important water resource in the basin [6]. Study area border is determined by taking account of hydrological (drainage network), topographical (valleys) and human activity (settlement) features in ways that involves areas at flood risk. Study area (Figure 2) includes Akarcay River from Afyonkarahisar Airport vicinity to Eber Lake and its tributaries (Seydiler Spring, Kali Creek and Degirmendere). Slope and aspect maps of study area whose average height is $1096 \mathrm{~m}$, average slope is $5^{0}$, average annual rainfall is $406 \mathrm{~mm}$ and mean yearly temperature is $11.2 \mathrm{C}^{0}$, are presented in Figure 3. Precipitation and temperature data are derived from meteorological stations of Turkish State Meteorological Service by using areal interpolation techniques. In study area, mean flow of Akarcay River is about $3 \mathrm{~m}^{3} / \mathrm{s}$ that is obtained from General Directorate of State Hydraulic Works. Drainage network, sub-basins, slope, aspect, rainfall, temperature and evaporation maps of study area are derived by spatial hydrology, surface and areal interpolation analyses on DEM. Settlement areas and lakes in study area are transferred into GIS platform by digitizing from satellite images. 


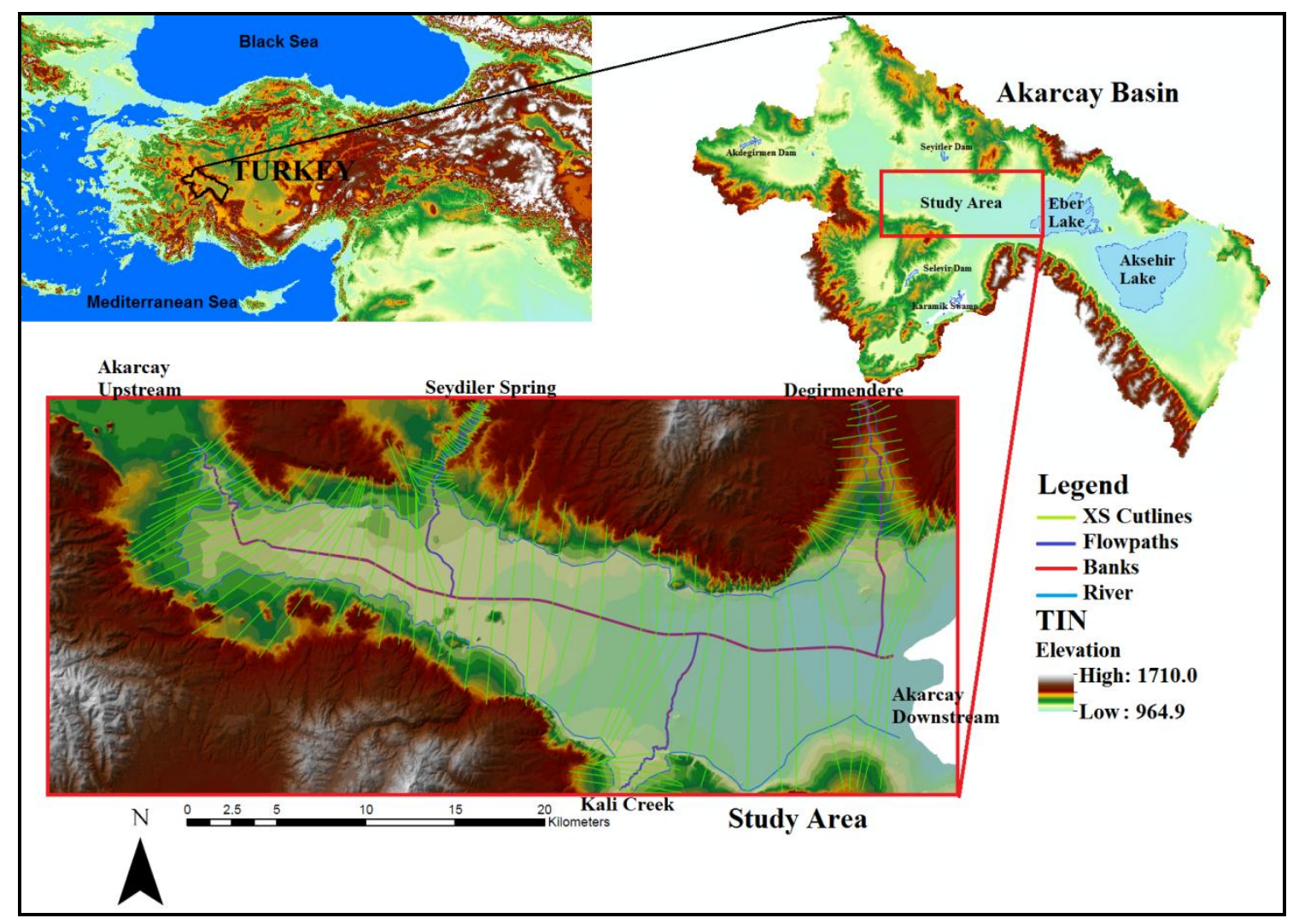

Figure 2. Geographical position of study area

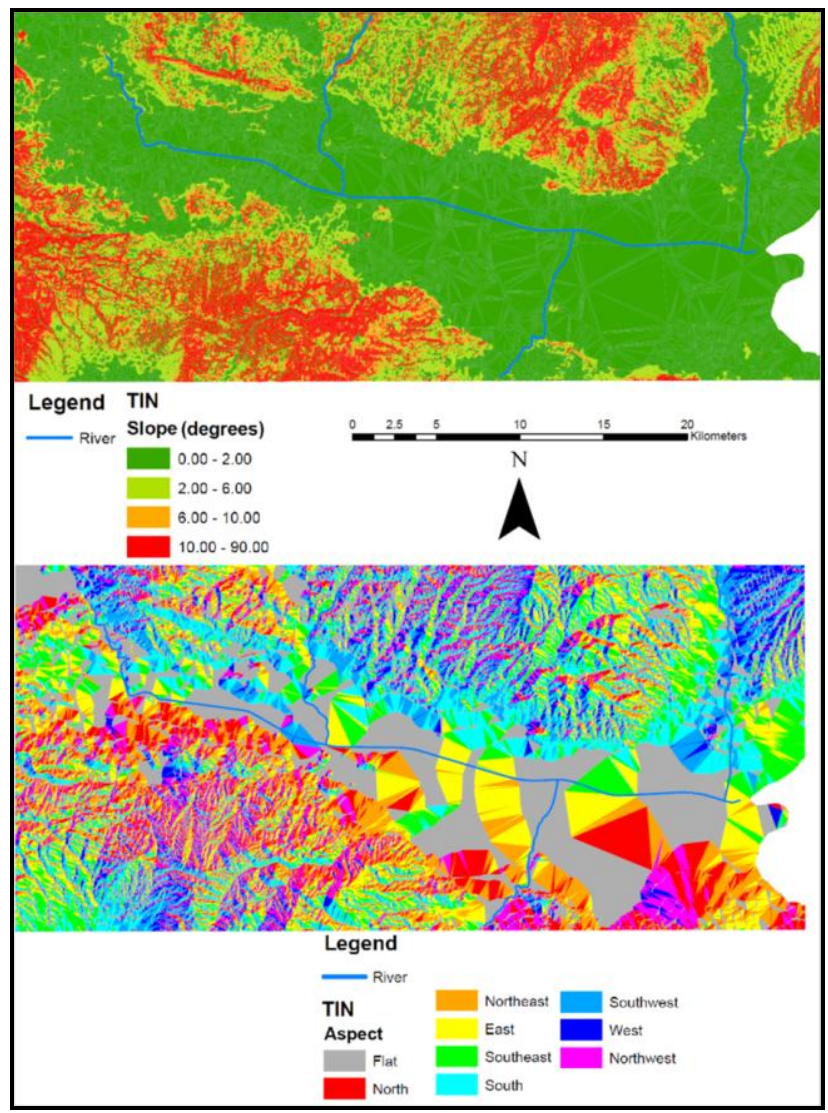

Figure 3. Slope and aspect maps of study area 
GIS Based Hydraulic Modelling: GIS is a crucial decision support system in numerous fields as well as water resources branch for collection, storage, compilation, selection by location, spatial analyses and presentation processes of data. ArcGIS, a software of ESRI (Environmental Systems Research Institute, California) is a GIS packaged software that can performed mapping, geographical analyses, data organization, data management and visualization operations by integrated interfaces. Creation GIS base of hydraulic model provides integration of between hydraulic model and hydro-meteorological, geomorphologic, topographical, human geography characteristics. Therefore, GIS based hydraulic modeling with GIS features enables decision makers to take decision easily.

In this study, ArcGIS is used in pre-process and post-process stages of hydraulic modeling. TIN (Triangulated Irregular Network) layer, base of hydraulic model is prepared by using contour lines derived from DEM (Grid resolution: 10mx10m), provided from General Command of Mapping (Turkish National Mapping Agency).

HEC GeoRAS is a subprogram in ArcGIS that supplies transfer of required topographic and geometric data with GIS base into the model. Input data into the model can be manual, but using HEC GeoRAS provides integration of GIS and hydraulic model. In the same breath, it is provided that input data into the model is quicker and more detailed. Required topographic and geometric data (stream centerline, bank lines, flow paths, cross sections, river reaches, junction point and tributary angle) for running model are obtained on TIN data by HEC GeoRAS and export file created to import into HEC RAS software.

Flood flow data (Recurrence intervals: 100 and 500 years) is calculated by Fuller method, an empirical approach. Constants derived from the basins in USA 10 years data is required for sufficient reliability. The coefficient $C_{f}$ varies from 0.026 to 2.77 ; $T$, recurrence interval in years. Fuller was the first to suggest that frequency should be considered as a factor in estimating floods. The exponent 0.8 is the slope of the line obtained by plotting the mean annual flood against watershed area for a number of streams. Almost all observed data till to-date confirm this value originally obtained by Fuller. Fuller formula is as below [7].

$\mathrm{Q}_{\mathrm{T}}=\mathrm{c}_{\mathrm{f}} * \mathrm{~A}^{0.8} *(1+0.8 \log \mathrm{T}) *\left(1+2.67 \mathrm{~A}^{-0.3}\right.$

$\mathrm{Q}_{\mathrm{T}}$ : Flood discharge for T return period $\left(\mathrm{m}^{3} / \mathrm{s}\right)$

$\mathrm{C}_{\mathrm{f}}$ : Fuller constant $(0,026-2,770)\left(\mathrm{C}_{\mathrm{f}}\right.$, Akarcay Basin $\left.=0,1\right)$

A: Basin area $\left(\mathrm{km}^{2}\right)$

$Q_{\text {mean,Akarcay Upstream }}=2.616 \mathrm{~m}^{3} / \mathrm{s}$

$A_{\text {Akarcay Upstream Subbasin }}=1669.840 \mathrm{~km}^{2}$

$\mathrm{Q}_{\text {mean,Seydiler Spring }}=0.419 \mathrm{~m}^{3} / \mathrm{s}$

$A_{\text {Seydiler Spring Subbasin }}=510.952 \mathrm{~km}^{2}$

$\mathrm{Q}_{\text {mean,Kali Creek }}=1.125 \mathrm{~m}^{3} / \mathrm{s}$

$\mathrm{A}_{\text {Kali Creek Subbasin }}=988.450 \mathrm{~km}^{2}$

$\mathrm{Q}_{\text {mean,Degirmendere }}=0.088 \mathrm{~m}^{3} / \mathrm{s}$

$A_{\text {Degirmendere Subbasin }}=336.065 \mathrm{~km}^{2}$

Flow data is inputted into the model by considering worst-case scenario (floods has same return period in all of river reaches) from the point of flood. In addition, flood discharge damping effect of dams (Seyitler and Selevir Dams) on Seydiler Spring and Kali Creek is not taken in consideration for staying on the safe side in flood risk assessment. 
HEC RAS (Hydrologic Engineering Center River Analysis System), developed by USACE (US Army Corps of Engineers) is used in hydraulic modeling. HEC RAS allows to perform one-dimensional (1D) steady and unsteady flow, sediment transport, mobile bed computations, and water temperature modeling [8]. Regularization of base geometric data and identification of hydraulic structures/situations (bridges, culverts, reservoirs, pump stations, levees, weirs, gates, obstruction and ineffective areas, land use, Manning roughness coefficient, streambed slope and ice cover) are practicable in HEC RAS. In this manner, many variables can defined in HEC RAS software. By inputting flow data into HEC RAS, water surface profiles and flood characteristics (inundation areas, flow depths and velocities, flow area and volume etc) are derivable for steady/unsteady flow. Most improtant factors of flood risk assessment are inundation area, flow depth and velocity. The model is made prepared to run for steady flow state by making required editing of input data and entering flow data (Figure 4). Profiles of streams; rating curves; flow depths and velocities; flow areas, widths and volumes; and water surfaces of cross sections besides of flood inundation outputs are also obtained by HEC RAS.

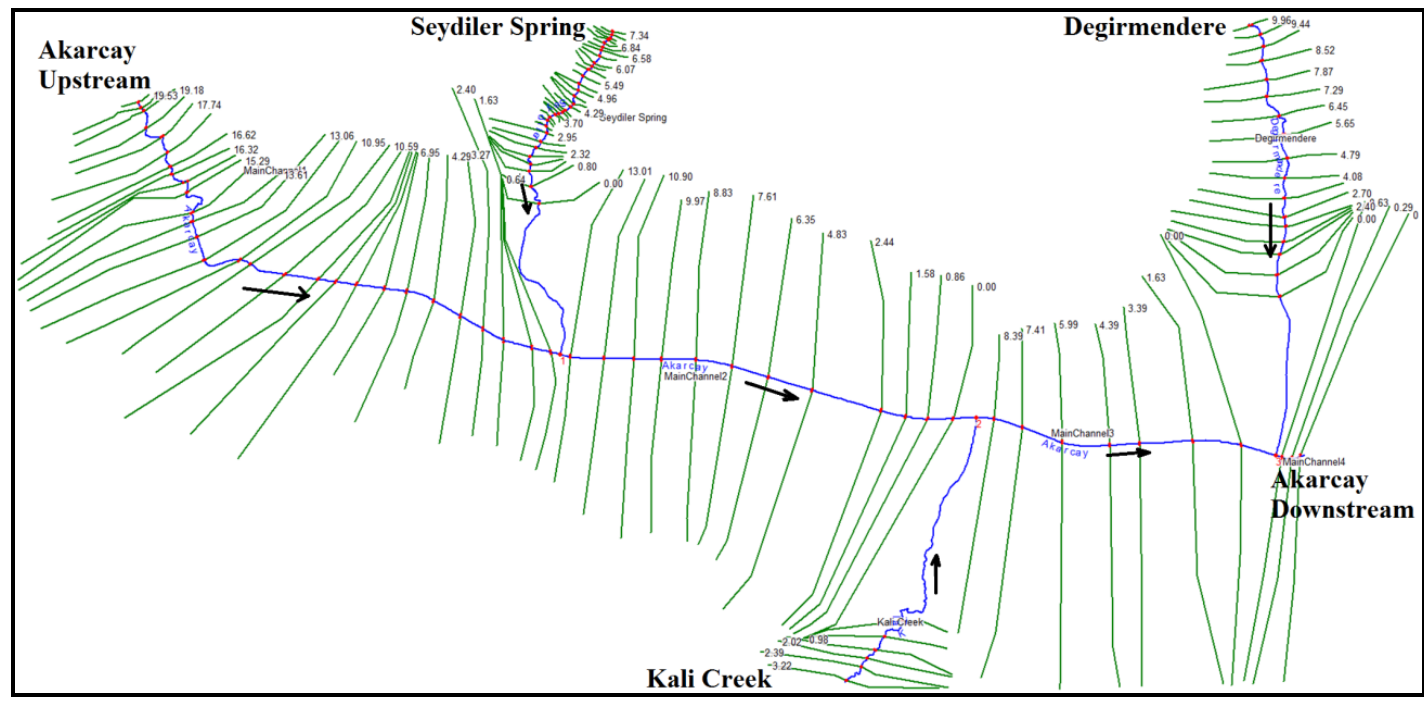

Figure 4. HEC RAS view of study area

Thereafter, areas at flood risk are determined by transferring HEC RAS flood inundation outputs into ArcGIS by way of HEC GeoRAS module (export-import processes) and enriching the visualization (overlay of flood outputs on satellite image etc).

\section{RESULTS AND DISCUSSION}

Steady flow data calculated for different return periods by Fuller method is given in Table 1.

Table 1. Steady flow data $\left(\mathrm{m}^{3} / \mathrm{s}\right)$

\begin{tabular}{lccc}
\hline River Reach & $\mathrm{Q}_{\text {mean }}$ & $\mathrm{Q}_{100}$ & $\mathrm{Q}_{500}$ \\
\hline Akarcay Upstream & 2.616 & 126.794 & 154.064 \\
\hline Seydiler Spring & 0.419 & 53.858 & 65.441 \\
\hline Kali Creek & 1.125 & 86.530 & 105.140 \\
\hline Degirmendere & 0.088 & 40.023 & 48.631 \\
\hline
\end{tabular}


100 and 500 years flood inundation maps of study area are presented in Figure 5.

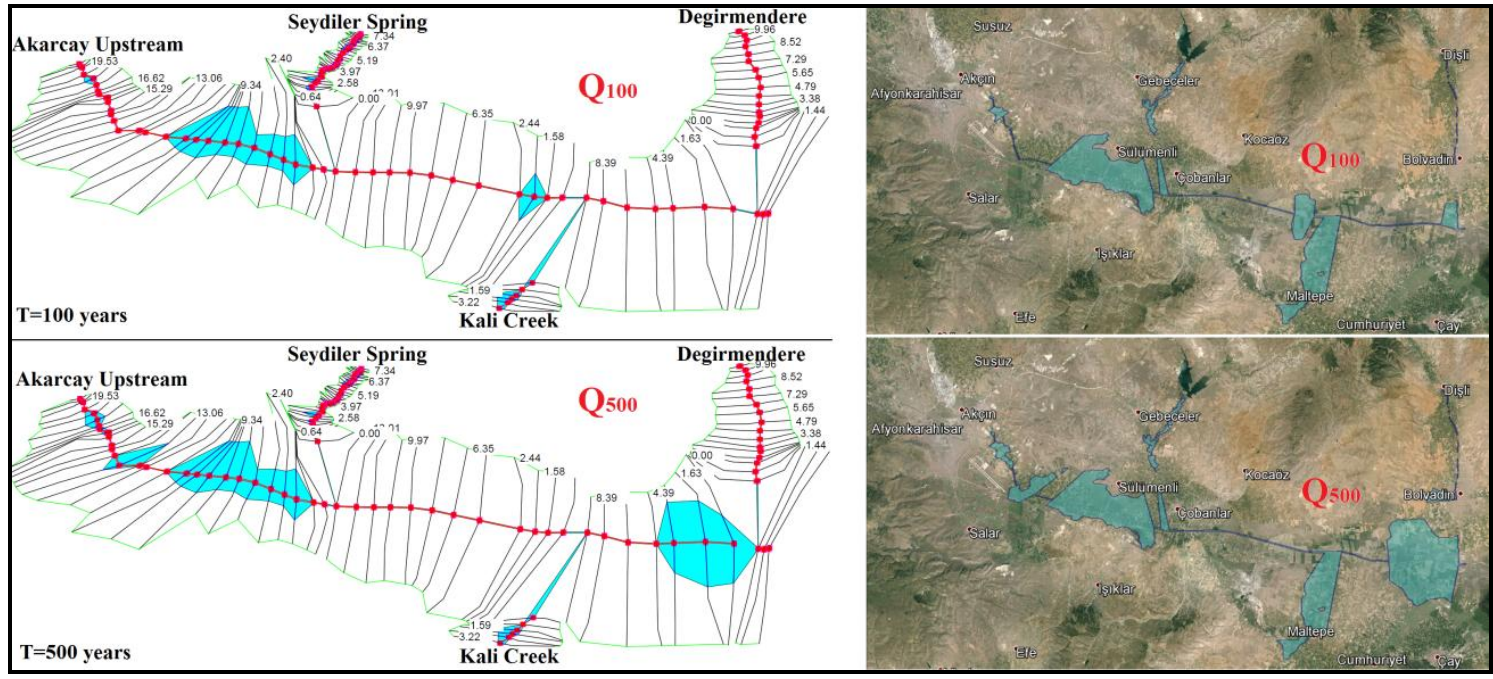

Figure 5. HEC RAS views and maps on satellite image of flood inundation of study area for 100 and 500 years return periods

Flood characteristics of study area can seen the table below. Flow velocity values for mean discharge are as follows on the purpose of understanding velocity grade: Mean flow velocity $0.25 \mathrm{~m} / \mathrm{s}$; max flow velocity $1.13 \mathrm{~m} / \mathrm{s}$ and $\min$ flow velocity $0.01 \mathrm{~m} / \mathrm{s}$.

Table 2. Flood characteristics of study area

\begin{tabular}{cccc}
\hline \multirow{2}{*}{ Flood Indicators } & & \multicolumn{2}{c}{ Flood Discharge } \\
\cline { 2 - 4 } & & $\mathrm{Q}_{100}$ & $\mathrm{Q}_{500}$ \\
\hline \multicolumn{2}{c}{ Flow Area $\left(1000 \mathrm{~m}^{2}\right)$} & 115748.89 & 159510.87 \\
\hline \multirow{2}{*}{ Flow Volume $\left(1000 \mathrm{~m}^{3}\right)$} & 1522613.16 & 1888338.20 \\
\cline { 2 - 4 } Flow Depth $(\mathrm{m})$ & Max & 1.84 & 2.02 \\
\cline { 2 - 4 } & Min & 0.23 & 0.33 \\
\cline { 2 - 4 } & Mean & 0.92 & 1.05 \\
\hline \multirow{3}{*}{ Flow Velocity $(\mathrm{m} / \mathrm{s})$} & Max & 3.29 & 3.51 \\
\cline { 2 - 4 } & Min & 0.01 & 0.01 \\
\cline { 2 - 4 } & Mean & 1.28 & 1.25 \\
\hline
\end{tabular}

When 100 and 500 years floods are evaluated, max flow depths are respectively $184 \mathrm{~cm}$ and $202 \mathrm{~cm}$. When max flow velocities are considered, they are rather hazardous in terms of flood undamaging potential in that floods with especially adrift materials (trees, rocks, vehicles, sediment etc) can cause substantial damages. Flow areas also vary between $116-160 \mathrm{~km}^{2}$ for 100 and 500 years return periods.

When inundation areas are examined, it is seen that mostly agricultural areas, Afyonkarahisar waste water treatment facility and sugar factory, small parts of several little settlements, some parts of express highway and railway are submerged. In study area, most of flood damage is originated from agricultural losses. In addition, damaging of waste water treatment plant is an important problem and disruption of transportation can cause great indirect economical losses. Be damaged probability of energy, fuel and 
communication transmission lines can increase substantially flood losses. And there is also that stoppage/failure of public services due to flood is a significant negative effect of floods.

\section{CONCLUSION AND RECOMMENDATIONS}

In this paper, study area is evaluated for flood risk by GIS based hydraulic modelling. Lately, in hydrology and water resources management, remote sensing (RS) and GIS tools are used frequently as vital decision support systems in preparation of flood management plans. In before, during and after flood, RS and GIS are helped to decision makers for required analyses (flood inundation, risk and hazard mapping; flood damage analysis; sufficiency and necessity of structural precautions; etc). In flood management as a part of integrated basin management, management success is increased by using RS and GIS tools in a wide range of from data supply to required analyses.

Flood inundation time, flow depth and velocity maps can be derived and overlaid to obtain flood risk (hazard) map. Multiplication of flow depth and velocity based flood hazard assessments can also performed. Land use and population features and flood risk map can considered together to create flood damage (vulnerability) map qualitatively and quantitatively. Furthermore, population features and density, building robustness with regards to collapse and evacuation planning based life loss estimation can be made. Flood risk maps created by using ground survey or DEM/DTM (Digital Terrain Model) endued with higher spatial resolution can considered to compare with available model outputs and to evaluate performance of flood control structures.

It is provided that rainfall/runoff based flood early warning system, dissemination of flood risk and evacuation planning are realised. Flood disaster insurance must be promoted based upon flood risk assessment. Education and consciousness raising studies; effective use of communication elements; good organization of relevant public establishments, nongovernmental societies and community; inter-institutional coordination and crisis desk must made actual within the frame of participative management approach.

\section{ACKNOWLEDGEMENT}

It is supported as part of project no 15. MUH. 09 which is accepted by Afyon Kocatepe University Coordinatorship of Scientific Research Projects.

\section{REFERENCES}

[1] Hasan Ozdemir. Flood risk analysis for different scenarios: A case study of Havran Creek (Balikesir), Association of Turkish Consulting Engineers And Architects Disaster Symposium, Turkey, pp 155-165, 2007.

[2] http://www.mgm.gov.tr/arastirma/dogal-afetler.aspx?s=taskinlar, Date Accessed: 12.12.2015.

[3] Halil Ibrahim Burgan. Flood modelling of Akarcay basin, MSc Thesis, Afyon Kocatepe University, Turkey, 2013.

[4] http://www.preventionweb.net/english/hazards/statistics/?hid=62, Date Accessed: 12.12.2015. 
[5] J-M. Scheuren \& O. le Polain deWaroux \& R. Below \& D. Guha-Sapir \& S. Ponserre. Annual disaster statistical review: the numbers and trends 2007, Centre for Research on the Epidemiology of Disasters (CRED), Belgium, 2008.

[6] https://tr.wikipedia.org/wiki/Akarçay_Havzası, Date Accessed: 12.12.2015.

[7] H. M. Raghunath. Hydrology: Principles, Analysis and Design, New Age International Publishers, India, pp 214, 2006.

[8] USACE Hydrological Engineering Center. HEC-RAS 4.1 Reference Manual. Approved Public Release, USA, 2010. 